\title{
PENGEMBANGAN MULTIMEDIA "USER EDUCATION" UNTUK MENINGKATKAN PEMAHAMAN PEMUSTAKA DALAM MEMANFAATKAN FASILITAS LAYANAN PADA PERPUSTAKAAN UNIVERSITAS PENDIDIKAN GANESHA
}

\author{
N P Pramita Utami ${ }^{1}$, I K Agus Sugika Putra ${ }^{2}$, N Angela Datta ${ }^{3}$ \\ ${ }^{1,2,3}$ UPT. Perpustakaan, Universitas Pendidikan Ganesha \\ Singaraja, Indonesia \\ E-mail: pramitautami@yahoo.com
}

\begin{abstract}
The aims of this study were to: (1) develop multimedia user education to improve the user understanding in utilizing the facilities services at Undiksha library, (2) determine the quality of multimedia user education based on expert validation, and (3) determine the effectiveness of multimedia user education postimplementation. This research was a multimedia development by adopting a model of Luther. The subjects of this study were user, librarian and programmer, and the research objects were multimedia user education, responses of user, librarian and programmer. Data were collected through questionnaires, interviews and observation. The collected data were analyzed descriptively. This research has successfully developed multimedia user education through six stages, namely, concept, design, material collecting, assembly, testing, and distribution. Based on the results of media experts' validation and librarians, multimedia user education deserves to be implemented as an instructional toolfor user education. Multimedia user education is very effective to be implemented in user education activities with the acquisition percentage of $88.1 \%$. The usefulness of multimedia user education reflected in the increased of understanding, motivation and user attitude to utilize the resources available in the Undiksha library. The multimedia is expected to be served as guidelines in user education at the library of Undiksha.
\end{abstract}

Key words: multimedia, user education, library services

\section{PENDAHULUAN}

Pendidikan pemustaka atau yang diistilahkan dengan user education, merupakan sebuah usaha peningkatan layanan perpustakaan yang bertujuan untuk mengenalkan segala fasilitas, layanan, jenis koleksi dan kebijakan kepada pengguna supaya dapat dimanfaatkan secara maksimal. Pendidikan pemustaka sesungguhnya bertujuan untuk menyadarkan pemustaka pada hakekat dan fungsi perpustakaan yang merupakan sumber informasi dan atau pengetahuan (Junaeti, 2013). Terkait dengan 
tujuan tersebut, pendidikan pemustaka juga diharapkan dapat meningkatkan keterampilan pemustaka dalam memanfaatkan sumber daya yang tersedia di perpustakaan sekaligus membentuk pemustaka sebagai pebelajar yang mandiri.

Pendidikan pemustaka biasanya diberikan kepada para mahasiswa baru pada masa OKK (oientasi kegiatan kampus) atau saat pertama kali berkunjung ke perpustakaan. Namun, semenjak lima tahun terakhir kegiatan user education sebagai bentuk sosialisasi perpustakaan tidak lagi menjadi agenda panitia OKK. Oleh karena itu, kegiatan user education hanya berlangsung onsite atau langsung di meja pustakawan pada saat pemustaka menemui kendala. Namun demikian, sering pula pemustaka yang berkunjung ke perpustakaan Undiksha merasa enggan untuk bertanya karena malu atau menganggap diri sudah paham dengan seluk beluk perpustakaan.

Pemustaka sering tidak menyadari bahwa profil perpustakaan perguruan tinggi tidak serupa dengan perpustakaan pada waktu di sekolah dasar ataupun menengah yang minim fasilitas dan layanan. Persepsi yang kurang mendukung tersebut sering mengakibatkan disorientasi pemustaka. Kebingungan pemustaka terdeteksi dari awal memasuki gedung perpustakaan, dimana pemustaka harus melewati layanan statistik pengunjung, keanggotaan, peminjaman loker, layanan sirkulasi, layanan OPAC dan lainnya. Lebih jauh, pemustaka tidak mengerti dengan jenis-jenis bahan pustaka yang terdapat di perpustakaan seperti: buku, jurnal/terbitan berseri, karya ilmiah dosen dan mahasiswa, koleksi referensi serta audio visual. Tentunya, penguasaan informasi tentang perpustakaan seyogyanya sudah dipahami sebelum pemustaka masuk ke gedung perpustakaan, jika tidak ingin tersesat dan mengalami kesulitan dalam mencari sebuah bahan pustaka.

Selain itu, berdasarkan pengamatan dilapangan diperoleh beberapa data terkait dengan kegiatan user education. Pertama, kemampuan pemustaka memahami user education yang dilakukan secara onsite tergolong rendah. Kedua, pustakawan belum mampu memberikan user education secara komunikatif dan menarik. Ketiga, belum adanya standar bahan pembelajaran user education di perpustakaan terutama bahan ajar berbasis multimedia. Keempat, banyaknya jumlah pengunjung dalam suatu 
waktu berimplikasi pada tidak efektifnya kegiatan user education kepada pemustaka yang berkunjung dengan berbagai kepentingan. Sebagai contoh, ada pemustaka yang ingin mencari bahan referensi berupa jurnal dan karya ilmiah dosen/mahasiswa, ada yang bermaksud mencari biografi tokoh tertentu, ada yang belum memiliki kartu anggota, bebas pustaka dan kepentingan lainnya. Fenomena tersebut menggambarkan berbagai kepentingan yang sangat kompleks dalam waktu yang bersamaan. Hal ini menyebabkan staf yang bertugas pada bagian information desk kelabakan untuk memfasilitasi semuanya. Fenomena seperti itu sering berdampak pada kebingungan pemustaka saat berada di perpustakaan. Sumber informasi yang mereka butuhkan sering tidak bisa ditemukan dan akhirnya berimplikasi pada tingkat kepuasan pemustaka.

Beranjak dari fenomena tersebut, maka penulis tergerak untuk mengembangkan bahan ajar user education interaktif berbasis multimedia yang disinyalir sangat efektif diaplikasikan kepada pemustaka yang memiliki karakteristik sebagai kaum digital natives. Prensky (2001), menggolongkan masyarakat generasi sekarang ini sebagai "digital natives" yaitu generasi yang lahir pada era digital (kurang lebih dari tahun1990an). Karakteristik digital natives adalah menyukai segala sesuatu secara online, multitasking, bekerja secara berjejaring, mengakses secara random (hypertext), menyukai gambar interaktif dan puas dengan segala sesutau yang serba instan (Ku \& Saulier, 2009) dalam Mardina (2011). Pemustaka potensial perpustakaan Undiksha merupakan golongan digital natives yang memiliki preferensi serba digital. Dengan demikian, pengembangan multimedia user education ini diharapkan dapat membantu mengoptimalkan pemahaman pemustaka terhadap fasilitas layanan pada perpustakaan Undiksha.

Perubahan yang cepat dalam dunia teknologi beberapa tahun terakhir, tidak hanya menjangkiti dunia pendidikan namun juga bidang pendukung lainnya seperti perpustakaan, tidak dapat menghindar dari kemajuan TI yang pesat ini. Hal ini didukung oleh pernyataan Hermawan \& Zen (2010) mengenai paradigma baru perpustakaan sebagai sesuatu yang hidup, dinamis, segar menawarkan hal-hal baru, produk layanan inovatif, dan dikemas sedemikian rupa, sehingga apapun yang 
ditawarkan oleh perpustakaan akan menjadi atraktif, interaktif, edukatif dan rekreatif bagi pengunjungnya.

Pernyataan serupa juga dikemukakan oleh Ranganathan (Bapak pustakawan India) yang terkenal dengan lima prinsip perpustakaan seperti yang dikutip dari Soedibyo (1987) yaitu: (1) books are for use, (2) every reader his/her book, (3) every book its reader, (4) save the time of the reader, dan (5) library is a growing organism. Secara harfiah, lima prinsip perpustakaan tersebut dapat diartikan secara berurut bahwa buku harus digunakan, setiap pembaca harus mendapatkan buku yang diperlukan, setiap buku harus samai kepada pembaca, menghemat waktu pembaca, dan perpustakaan merupaan badan yang tumbuh.

Berdasarkan pernyataan tersebut dapat disimpulkan bahwa sebuah perpustakaan yang baik adalah perpustakaan yang selalu mengikuti dinamika perkembangan era informasi, sehingga kebutuhan informasi pemustaka dapat terpenuhi.

Perpustakaan Undiksha telah melakukan berbagai inovasi untuk memodifikasi layanan agar tidak ditinggalkan penggunanya yang nota bene merupakan generasi digital natives. Hal ini dilakukan merujuk pada perubahan konsep perpustakaan di era internet, sehingga sistem layanan perpustakaan dikembangkan sesuai dengan pola sikap dan perilaku pemustaka yang gandrung terhadap teknologi (Utami, 2012). Untuk itu, dalam memberikan layanan yang berbasis pada kepuasan pengguna, maka pihak perpustakaan mau tak mau harus melibatkan TI sebagai salah satu usaha mewujudkan layanan prima.

Hal tersebut sejalan dengan UU RI no 43 tahun 2007 tentang perpustakaan, terutama pada bab $\mathrm{V}$ pasal 14 menyangkut masalah layanan perpustakaan, mengungkapkan bahwa ada dua hal penting yang harus diperhatikan oleh perpustakaan dalam menyikapi perkembangan TI sekarang ini. Pada pasal (1) berbunyi: "Layanan perpustakaan dilakukan secara prima dan berorientasi bagi kepentingan pengguna. Dan, pasal (3) berbunyi: "Setiap perpustakaan mengembangkan layanan perpustakaan sesuai dengan kemajuan teknologi informasi dan komunikasi. 
Merujuk pada pentingnya keterlibatan teknologi informasi dan komunikasi dalam memberikan layanan prima kepada pemustaka perpustakaan Undiksha, maka tepatlah pengembangan bahan ajar multimedia user education yang dapat diakses oleh pemustaka melalui gadget ataupun smartphone kapanpun dan dimanapun dibutuhkan.

Istilah multimedia berkenaan dengan penggunaan berbagai jenis/bentuk media secara berurutan maupun simultan dalam menyajikan suatu informasi. Secara etimologi, kata multimedia berasal dari dua kata yaitu multi yang artinya banyak dan media yang artinya perantara (KBBI: 2003). Selanjutnya, Barfield (2004) memberikan definisi multimedia sebagai sebuah sistem yang interaktif dan menggunaan lebih dari dua perantara dalam sebuah sistem yang terintegrasi.

Dengan demikian, multimedia dapat didefinisikan sebagai kombinasi dari beberapa elemen/data/media untuk menyampaikan suatu informasi secara menarik, kreatif dan inovatif, sehingga memungkinkan pengguna dapat bernavigasi, berinteraksi, berkreasi dan berkomunikasi (Janiansyah, 2009). Selanjutnya, Merril et.al (1996: 168) dalam Wati (2010) memberikan pengertian multimedia merupakan kombinasi dari berbagai jenis media seperti teks, grafik, suara, animasi dan video dalam aplikasi komputer.

Sementara Hofstetter yang dikutip Suyanto (2005: 21) multimedia adalah pemanfaatan komputer untuk membuat dan menggunakan teks, grafik, audio, gambar bergerak (video dan animasi) dengan menggabungkan link dan tool yang memungkinkan pemakai melakukan navigasi, berinteraksi, dan berkomunikasi.

Lebih lanjut Hofstetter yang dikutip Suyanto (2005: 21) menyatakan ada empat komponen penting multimedia; (1) harus ada komputer yang mengkoordinasikan apa yang dilihat dan didengar, yang berinteraksi dengan pengguna, (2) harus ada link yang menghubungkan kita dengan informasi, (3) harus ada alat navigasi yang memandu pengguna menjelajah jaringan informasi, (4) multimedia menyediakan tempat kepada pengguna untuk mengumpulkan, memproses, mengkomunikasikan informasi dan ide. 
Berdasarkan dari berbagai definisi tersebut, maka secara operasional multimedia user education dapat didefinisikan sebagai sebuah bahan ajar interaktif untuk melakukan pendidikan pemakai (user education) yang merupakan hasil pemanfaatan teknologi komputer yang menggabungkan beberapa elemen seperti gambar, teks, grafik, animasi, audio dan video yang memungkinkan pemustaka untuk bernavigasi, berinteraksi dan berkomunikasi secara online. Materi ajar yang dimuat dalam multimedia user education secara umum adalah tata letak gedung perpustakaan, fasilitas, sistem layanan (layanan referensi, terbian berseri, audio visual, sirkulasi, keanggotaan, bebas pustaka, karya ilmiah dosen/mahasiswa, peminjaman locker, akses internet dan e-jurnal), tata tertib dan prosedur perpustakaan Undiksha, pengorganisasian koleksi, pemanfaatan Indian Corner dan BI Corner. Semua materi tersebut akan terangkum dalam bentuk multimedia yang dapat diakses secara mandiri oleh pemustaka perpustakaan Undiksha dengan fasilitas komputer, gadget, maupun smartphone, sehingga pemahaman pemustaka terhadap perpustakaan secara menyeluruh dapat terwujud.

Target utama dalam segala bentuk inovasi yang dilakukan oleh perpustakaan Undiksha adalah terbentuknya kepuasan pemustaka. Bentuk dari kepuasan pemustaka ini akan berpengaruh langsung terhadap minat mahasiswa dalam memanfaatkan perpustakaan (Nurdiyani, 2011). Berbagai masalah yang muncul terkait dengan pendidikan pemakai pada perpustakaan Undiksha seperti telah dipaparkan sebelumnya diharapkan akan terpecahkan dengan solusi pengembangan multimedia user education. Keterlibatan multimedia user education disinyalir sangat bermanfaat untuk memberikan gambaran menyeluruh tentang perpustakaan Undiksha. Terlebih multimedia interaktif ini sangat sesuai dengan pemustaka yang memiliki karakteristik sebagai kaum digital natives. Media pendidikan pemustaka yang interaktif ini akan di tautkan pada web perpustakaan Undiksha. Hal ini dapat meningkatkan pencitraan dan kredibilitas perpustakaan Undiksha di ruang publik.

Penelitian ini memiliki beberapa tujuan yaitu mengembangkan multimedia user education, memvalidasi multimedia dan menguji coba multimedia untuk mengetahui efektivitas produk. 


\section{METODE PENELITIAN}

\section{Desain Penelitian}

Penelitian ini bertujuan untuk mengembangkan, memvalidasi dan mengujicoba perangkat multimedia user education, sehingga dalam penyusunan kajian ini peneliti menggunakan desain penelitian pengembangan (research and development).

Pengembangan multimedia user education dilandasi oleh faktor belum adanya bahan ajar/sosialisasi yang interaktif dan inovatif yang dapat diakses melalui web, serta faktor karakteristik pemustaka sebagai kaum digital natives mendasari perlunya perubahan sistem ke kondisi ideal yang diharapkan.

Dengan demikian, sasaran atau objek kajian dari penelitian ini adalah perangkat multimedia user education, respon pemustaka, respon programmer dan respon pustakawan. Subyek dari penelitian ini adalah pemustaka perpustakaan Undiksha sebagai pemakai multimedia, ahli komputer/programmer sebagai perancang model/produk serta pustakawan sebagai tenaga ahli dalam bidang studi kepustakawanan.

\section{Populasi dan Sampel}

Seluruh pemustaka pada perpustakaan Undiksha merupakan populasi penelitian. Sedangkan, pemustaka yang berkunjung ke perpustakaan Undiksha yang kebetulan belum memahami fasilitas layanan yang tersedia pada perpustakaan Undiksha merupakan sampelnya. Rancangan pengambilan sampelnya menggunakan rancangan non-probabilitas (non-probability sampling) dengan teknik pengambilan sampel aksidental (accidental sampling). Menurut Faisal (2008), accidental sampling merupakan teknik pengambilan sampel "asal ambil atau asal pilih". Dalam hal ini, sampel terpilih merupakan pemustaka yang kebetulan menelusur/mencari informasi yang ada pada koleksi jurnal di perpustakaan Undiksha.

\section{Prosedur penelitian}

Penelitian ini merupakan penelitian pengembangan multimedia, sehingga model prosedur yang diadopsi dalam penelitian ini mengikuti model Luther. Alasan dipilihnya model Luther karena langkah-langkah pengembangannya sistematis, 
disajikan secara ringkas, dan dan setiap langkah dipaparkan secara jelas. Menurut Luther (Sudatha \& Tegeh, 2009) terdapat enam tahap dalam langkah pengembangan multimedia pembelajaran, yaitu concept, design, material collecting, assembly, testing, dan distribution, seperti pada gambar berikut.

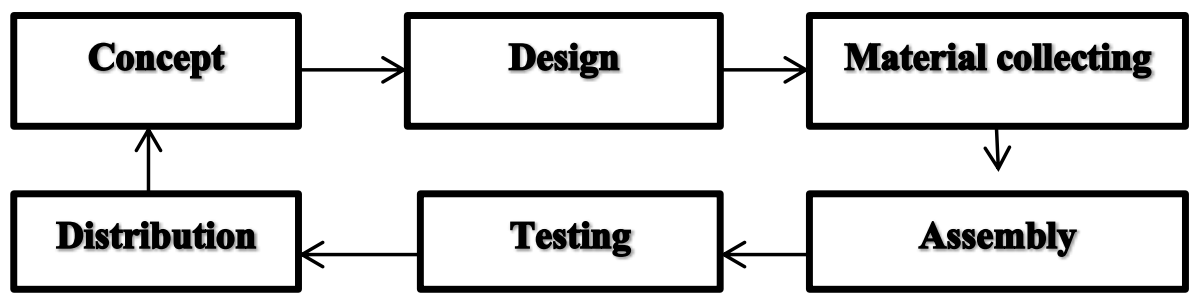

\section{Bagan 1. Tahap Pengembangan Multimedia menurut Luther}

\section{Instrumen Penelitian}

Peneliti menggunakan tiga buah instrumen dalam pengumpulan data yaitu dengan kuesioner, catatan observasi/pengamatan dan wawancara. Metode catatan pengamatan/observasi diterapkan dalam pengumpulan data, mempertimbangkan bahwa apa yang dikatakan seseorang sering kali berbeda dengan apa yang dilakukan, Bungin (2007). Dengan demikian, bias data dapat diminimalisir. Catatan observasi dilakukan dengan pemantauan sebelum dan sesudah pemanfaatan multimedia user education.

Angket merupakan alat pengumpulan data yang berisi kumpulan pernyataan tentang kajian yang akan diteliti yaitu pengembangan multimedia user education yang memuat lima butir indikator seperti materi multimedia, relevansi, kepuasan pemustaka, pengetahuan, dan sikap pemustaka terhadap multimedia.

Selanjutnya, wawancara tak berstruktur juga diterapkan dalam pengumpulan data. Teknik wawancara tak berstruktur diterapkan bertujuan untuk menggali informasi lebih lengkap dan akurat dari sisi responden. Data hasil wawancara kemudian merupakan data kualitatif. Berikut adalah tabel matriks pengumpulan data yang di desain dalam penelitian ini.

Tabel 1. Matriks Pengumpulan Data

\begin{tabular}{|c|c|c|c|c|}
\hline Instrumen & Sumber Data & Jenis Data & $\begin{array}{c}\text { Waktu } \\
\text { Penerapan }\end{array}$ & Sifat Data \\
\hline -Kuesioner & -Pemustaka & Respon pemustaka, ahli & Uji coba skala & Data kuantitatif \\
\hline
\end{tabular}




\begin{tabular}{|c|c|c|c|c|}
\hline & $\begin{array}{l}\text {-Ahli media } \\
\text {-Pustakawan }\end{array}$ & $\begin{array}{l}\text { media dan pustakawan } \\
\text { terhadap multimedia } \\
\text { user education }\end{array}$ & besar dan validasi & \\
\hline $\begin{array}{l}\text { Catatan } \\
\text { observasi }\end{array}$ & $\begin{array}{l}\text { Perilaku } \\
\text { pemustaka }\end{array}$ & $\begin{array}{l}\text { Tingkat pemahaman } \\
\text { pemustaka dalam } \\
\text { memanfaatkan } \\
\text { perpustakaan }\end{array}$ & $\begin{array}{l}\text { Sebelum dan } \\
\text { sesudah ujicoba }\end{array}$ & Data kuantitatif \\
\hline $\begin{array}{l}\text { Wawancara } \\
\text { tak } \\
\text { berstruktur }\end{array}$ & $\begin{array}{l}\text {-Ahli media } \\
\text {-Pustakawan } \\
\text {-Pemustaka }\end{array}$ & $\begin{array}{l}\text { Respon ahli media, } \\
\text { pustakawan } \\
\text { pemustaka }\end{array}$ & $\begin{array}{l}\text { Validasi ahli dan } \\
\text { revisi }\end{array}$ & Data kualitatif \\
\hline
\end{tabular}

\section{Analisis Data}

Data yang terkumpul melalui instrumen selanjutnya dianalisis. Merujuk pada dua model data yang dihasilkan (data kuantitatif dan kualitatif) maka ada dua teknik analisis data yang diterapkan. Analisis data kuantitatif dilakukan dengan pentabulasian data hasil kuesioner dan catatan observasi pemantauan perilaku pemustaka baru. Selanjutnya diterapkan teknik analisis deskriptif dari hitungan data kuantitatif. Tahapan dalam analisis data kualitatif yaitu melalui (1) mentranskripsi data, (2) pengelompokan data dan (3) menginterpretasikan data menggunakan teknik deskriptif.

\section{HASIL DAN PEMBAHASAN}

\section{Hasil}

\section{a. Deskripsi Multimedia User Education}

Multimedia User Education (MUE) merupakan sebuah sistem interaktif berbasis komputer yang terdiri dari beberapa elemen seperti teks, audio, video, grafik dan animasi yang terintegrasi dalam suatu penyajian yang mempresentasikan tentang materi pendidikan pemakai yang bertujuan untuk mengoptimalkan pemahaman pemustaka dalam memanfaatkan fasilitas layanan pada perpustakaan Undiksha.

MUE dikembangkan dengan merujuk pada pemgembangan multimedia model Luther. Model Luther memuat enam tahap pengembangan multimedia pembelajaran, yaitu concept, design, material collecting, assembly, testing, dan distribution. Berikut adalah beberapa tampilan dalam MUE. 


\section{USER EDUCATION}

- MEMPERKENALKAN FASILITAS dAN SUMBER dAYA / RESOURCES PERPUSTAKAAN

- MEMBANGUN KETRAMPILAN PERPUSTAKAAN

- MEWUJUdKan PEMUSTAKa SEbagaI PEL.AJAR YANg MANDiRI

- membangun citra perpustakaAn sebagai pusat aKtivitas aKedemis

- MEMBERIKan PEMAHAMan KONSEP SEHINGga PEMUSTAKa dapat MENGGUNAKAN MATERIAL DAN LAYANAN DENGAN EFISIEN

\section{Gambar 1. Tujuan MUE}

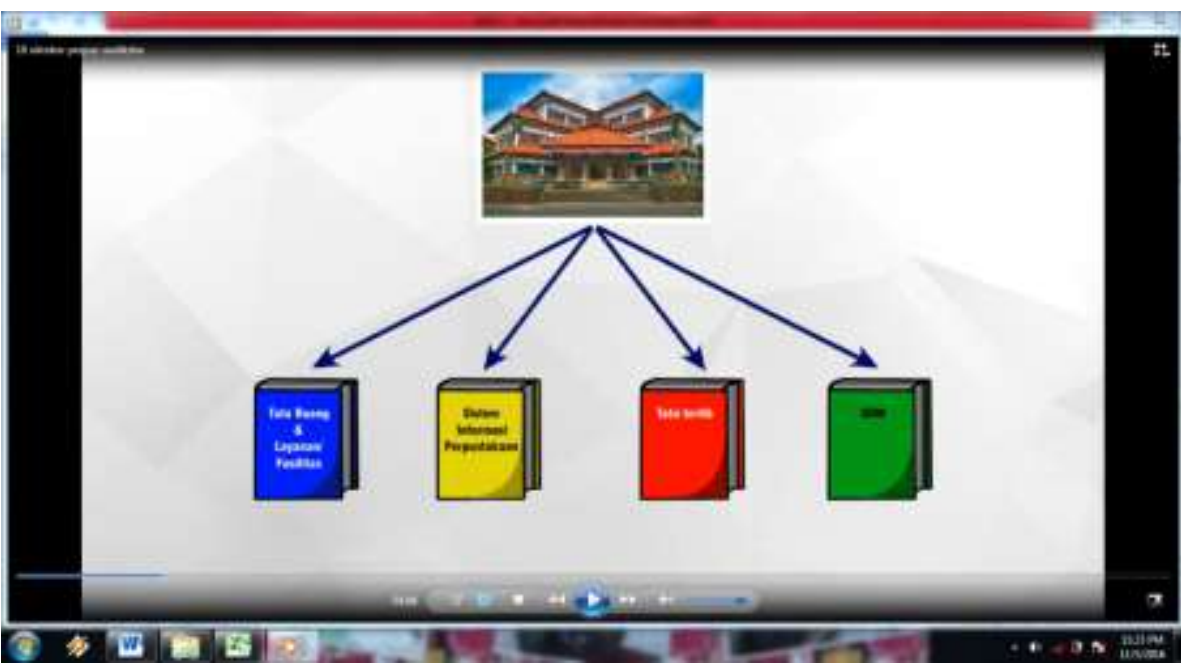

Gambar 2. Tampilan Aspek Utama dalam MUE

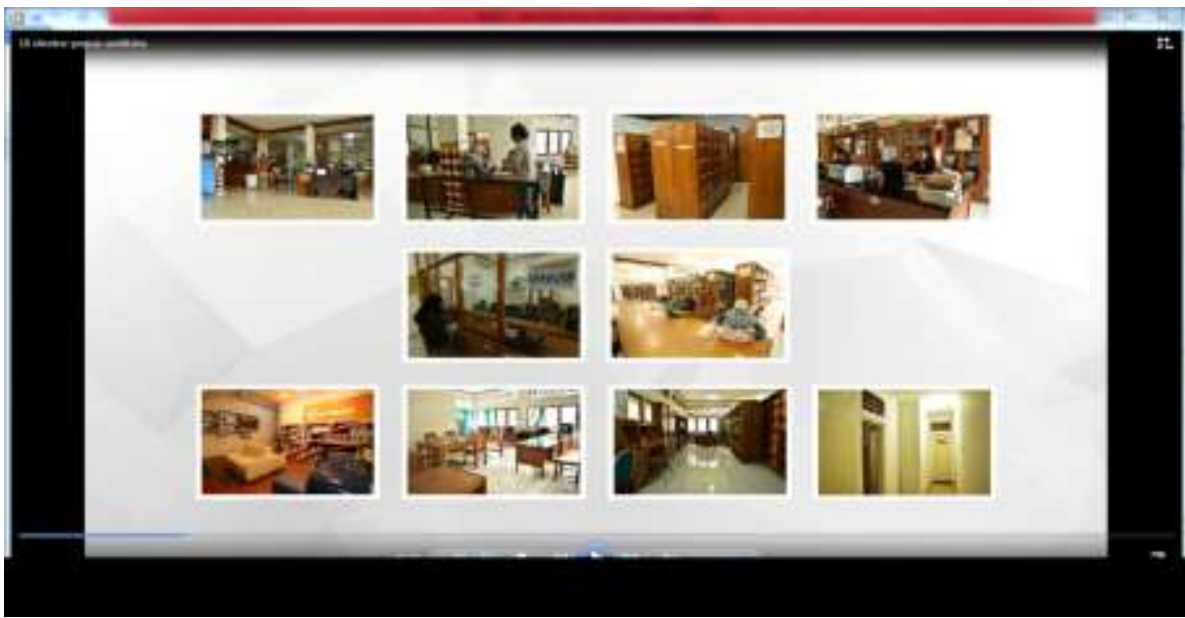

Gambar 3. Tampilan Lantai 1 


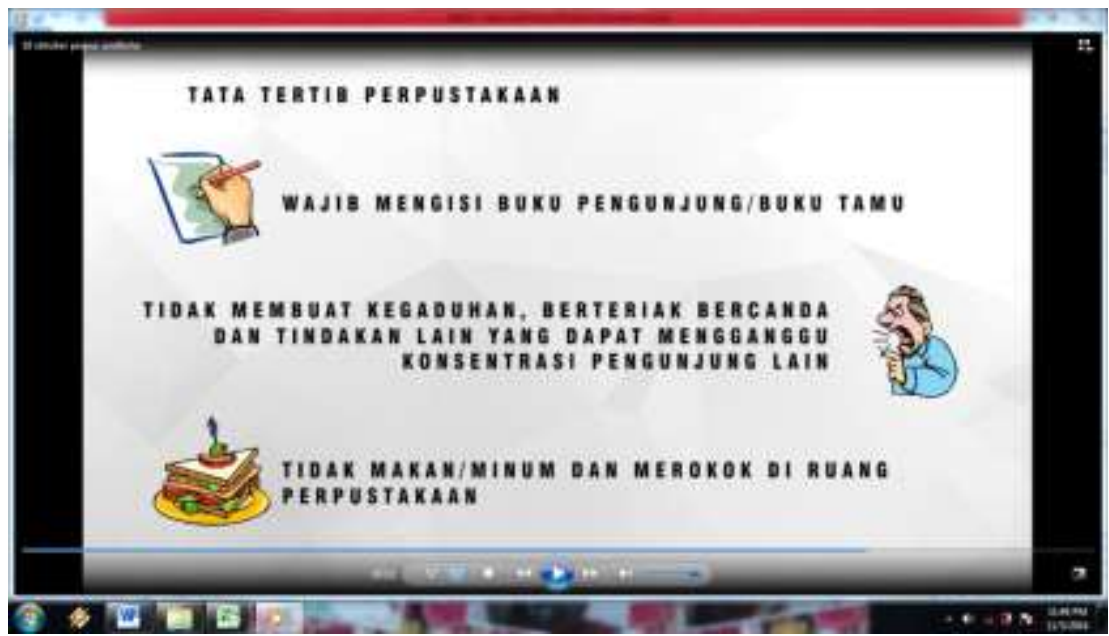

Gambar 4. Tampilan Tata Tertib Perpustakaan

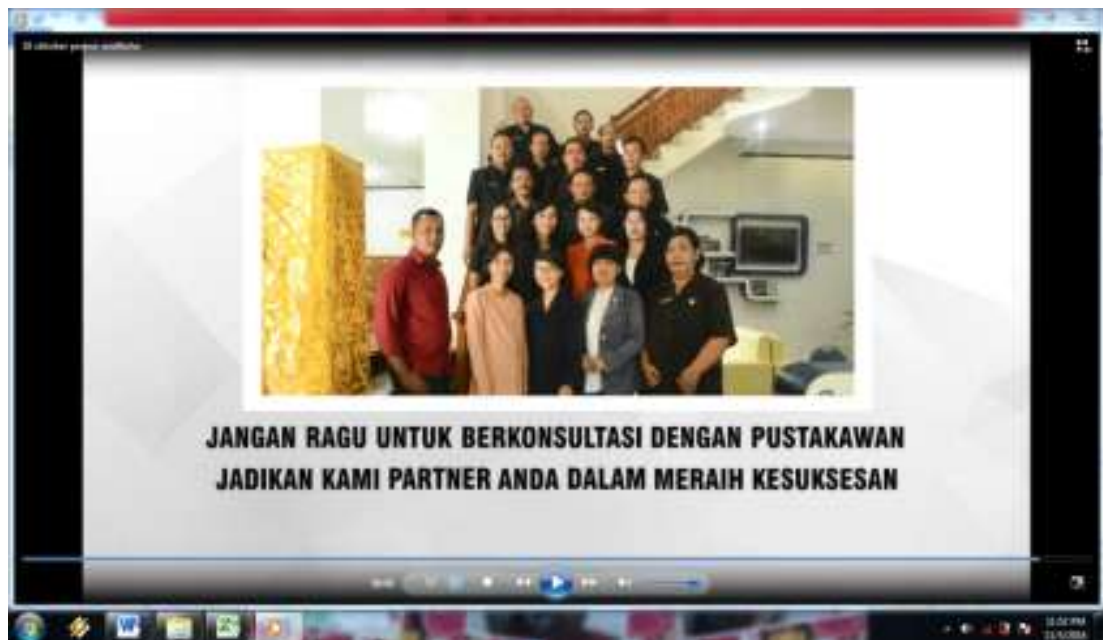

\section{Gambar 5. Tampilan Staf Pustakawan Undiksha}

\section{b. Validasi Multimedia User Education}

Validasi dilakukan untuk mengetahui sejauhmana multimedia yang dikembangkan dapat digunakan sebagai media pengajaran dalam pendidikan pemustaka, sehingga dapat diketahui tingkat kebenaran dan ketepatan penggunaan media tersebut. Validasi MUE dilakukan oleh tim validator ahli media dan pustakawan. Validasi menyangkut beberapa indikator seperti konten, tampilan, dan operasionalnya. Selanjutnya, instrumen angket diberikan kepada ahli media dan pustakawan untuk pengujian media. 


\section{1) Validasi Ahli Media}

Lembar angket diberikan kepada ahli media untuk memperoleh informasi mengenai standar mutu sebuah media yang telah dirancang, dalam hal ini multimedia user education. Terdapat lima aspek yang diukur dalam validasi ahli media sebagai berikut.

\section{Tabel 2. Data Validasi Ahli Media}

\begin{tabular}{|c|c|c|c|}
\hline \multirow[t]{2}{*}{ NO } & \multirow[t]{2}{*}{ ASPEK } & \multicolumn{2}{|c|}{ SKOR (1-5) } \\
\hline & & Ahli media 1 & Ahli media 2 \\
\hline 1 & Keterbacaan teks & 4 & 4 \\
\hline \multirow[t]{5}{*}{2} & Kualitas tampilan: & & \\
\hline & - $\quad$ kualitas tampilan gambar & 4 & 3 \\
\hline & penempatan gambar pada layar & 3 & 4 \\
\hline & kualitas tampilan animasi & 4 & 3 \\
\hline & kualitas warna & 4 & 4 \\
\hline 3 & Kemudahan navigasi & 4 & 4 \\
\hline 4 & Kualitas audio & 3 & 3 \\
\hline \multirow[t]{3}{*}{5} & Kualitas pengelolaan program & 4 & 4 \\
\hline & Rerata & 3.75 & 3.62 \\
\hline & Total rerata & \multicolumn{2}{|c|}{3.68} \\
\hline
\end{tabular}

Keterangan:

5 = sangat layak

4 = layak

3 = cukup layak

2 = kurang layak

$1=$ tidak layak

$$
\begin{aligned}
& 4.21-5=\text { sangat layak } \\
& 3.41-4.20=\text { layak } \\
& 2.61-3.40=\text { cukup layak } \\
& 1.81-2.60=\text { kurang layak } \\
& 0-1.8=\text { sangat kurang layak }
\end{aligned}
$$

Tabel 2 merupakan hasil validasi ahli media yang berjumlah dua orang. Total rerata yang diperoleh dari validasi ahli media adalah 3.68, yang bila dikonversikan pada tabel penilaian angka tersebut termasuk dalam kategori layak. Rerata yang diperoleh dari validasi ahli media 1 adalah 3.75 yang bila dikonversikan pada tabel penilaian, maka angka tersebut termasuk dalam kategori layak. Secara terperinci, ahli media 1 memberikan skor 4 untuk 6 aspek seperti aspek keterbacaan teks, kualitas tampilan gambar, kualitas tampilan animasi, kualitas warna, kemudahan navigasi, dan kualitas pengelolaan program. Sedangkan skor 3 diberikan untuk 2 aspek seperti penempatan gambar pada layar dan kualitas audio. 
Selanjutnya, rerata yang diperoleh dari validasi ahli media 2 adalah 3.62 yang bila dikonversikan pada tabel penilaian, maka angka tersebut termasuk dalam kategori layak. Secara terperinci, ahli media 2 memberikan skor 4 untuk lima aspek seperti aspek keterbacaan teks, kualitas tampilan penempatan gambar pada layar dan kualitas warna, kemudahan navigasi, serta kualitas pengelolaan program. Sedangkan untuk aspek kualitas tampilan gambar, kualitas tampilan animasi, dan kualitas audio diberikan skor 3 .

\section{2) Validasi Pustakawan}

Validasi kualitas konten multimedia user education (MUE) dari pustakawan dilakukan untuk mengetahui beberapa aspek seperti berikut.

Tabel 3. Data Validasi Pustakawan

\begin{tabular}{|c|c|c|c|}
\hline \multirow[t]{2}{*}{ NO } & \multirow[t]{2}{*}{ ASPEK } & \multicolumn{2}{|c|}{ SKOR (1-5) } \\
\hline & & Pustakawan 1 & Pustakawan 2 \\
\hline 1 & Kejelasan tujuan MUE & 5 & 5 \\
\hline 2 & Kesesuaian materi dengan indikator & 5 & 5 \\
\hline 3 & Kejelasan uraian materi & 4 & 4 \\
\hline 4 & Ketepatan urutan materi & 4 & 4 \\
\hline 5 & Ketepatan animasi yang ditampilkan & 4 & 4 \\
\hline 6 & Pemberian motivasi & 4 & 4 \\
\hline 7 & Kejelasan bahasa & 4 & 4 \\
\hline & Rerata & 4.29 & 4.29 \\
\hline & Total rerata & \multicolumn{2}{|c|}{4.29} \\
\hline
\end{tabular}

Keterangan:

5 = sangat layak

4 = layak

3 = cukup layak

$2=$ kurang layak

$1=$ tidak layak

$$
\begin{aligned}
& 4.21-5=\text { sangat layak } \\
& 3.41-4.20=\text { layak } \\
& 2.61-3.40=\text { cukup layak } \\
& 1.81-2.60=\text { kurang layak } \\
& 0-1.8=\text { sangat kurang layak }
\end{aligned}
$$

Tabel 3 menunjukkan bahwa total rerata hasil validasi pustakawan adalah 4.29. Angka tersebut jika dikonversikan pada tabel penilaian maka termasuk dalam kategori sangat layak. Secara terperinci, diperoleh rerata sejumlah 4.29 dari 
pustakawan 1 dan 2 yang bila dikonversikan pada tabel penilaian tergolong dalam kategori sangat layak. Skor 5 diberikan pada aspek kejelasan tujuan MUE dan kesesuaian materi dengan indikator, sedangkan skor 4 diberikan pada aspek kejelasan uraian materi, ketepatan urutan materi, ketepatan animasi yang ditampilkan, pemberian motivasi dan kejelasan bahasa.

\section{c. Efektivitas Multimedia User Education (MUE)}

Untuk mengetahui tingkat kebermanfaatan media yang telah dikembangkan, maka diperlukan adanya pengukuran efektifitas. Terkait dengan hal itu, multimedia yang telah dikembangkan diujicobakan kepada 50 responden terutama mahasiswa baru angkatan 2016 yang diambil secara accidental random sampling. Instrumen angket diberikan kepada pemustaka setelah menonton MUE.

Angket diukur dengan menggunakan skala Likert dari rentang STS, TS, N, S dan SS. Angket memuat lima indikator seperti terlihat pada tabel 4.3 berikut.

Tabel 4. Indikator Angket MUE

\begin{tabular}{clc}
\hline NO & \multicolumn{1}{c}{ INDIKATOR } & JUMLAH \\
\hline 1 & Materi MUE & 9 \\
2 & Relevansi MUE & 4 \\
3 & Kepuasan pemustaka & 3 \\
4 & Pengetahuan & 6 \\
5 & Sikap pemustaka terhadap MUE & 8 \\
\multicolumn{2}{c}{ Total } & $\mathbf{3 0}$ \\
\hline
\end{tabular}

\section{Pembahasan}

Multimedia user education (MUE) telah dikembangkan dengan model Luther. Enam tahap pengambangan telah dilalui dalam proses pengembangan MUE yaitu dari tahap concept, design, material collecting, assembly, testing, dan distribution. Penentuan nama multimedia, tujuan, audiens, durasi waktu, dan latar belakang program merupakan bagian dari pembuatan konsep MUE. Dilanjutkan dengan perancangan desain media, pengumpulan materi media seperti foto, audio, bagan, animasi, dan lain-lain yang kemudian dirakit (assembly) menjadi media pembelajaran 
pendidikan pemustaka. MUE kemudian divalidasi oleh ahli media dan ahli materi (pustakawan), serta uji terbatas terhadap pemustaka. Berdasarkan hasil validasi, MUE direvisi untuk mendapatkan hasil akhir yang baik, relevan dan menarik. Produk akhir MUE selanjutnya didistribusikan kepada pemustaka baru yang berkunjung ke perpustakaan Undiksha. Sejalan dengan tujuan pengembangan media pendidikan pemustaka, MUE mampu memberikan pengenalan awal terhadap tata ruang, layanan, fasilitas, sistem informasi perpustakaan, tata tertib, SDM, dan motto perpustakaan Undiksha, sehingga pemustaka tidak canggung memanfaatkan sumber daya dalam perpustakaan. Validasi terhadap kualitas MUE dilakukan oleh tim ahli media dan ahli materi (pustakawan). Berikut adalah grafik hasil validasi ahli media.

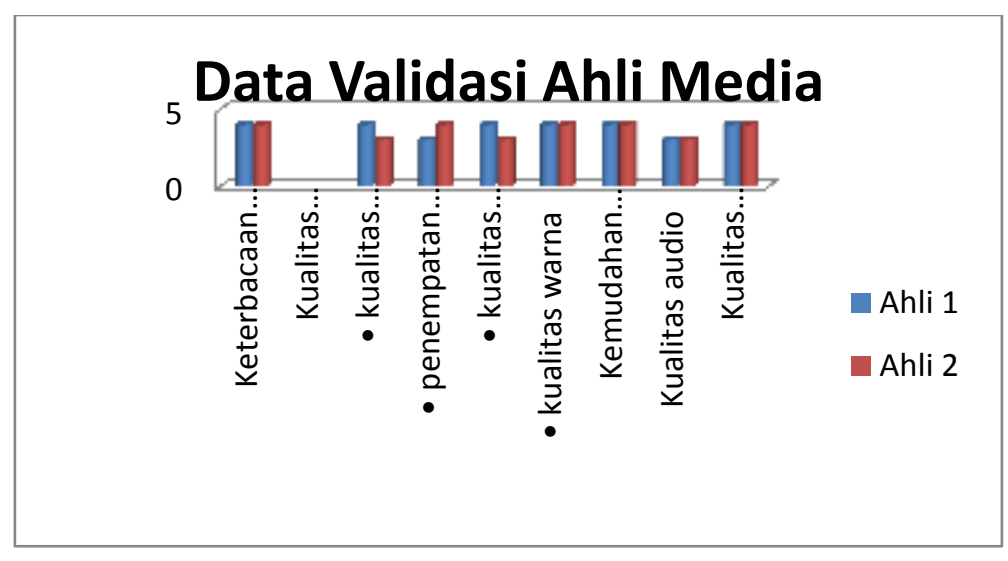

\section{Grafik 1. Data Validasi Ahli Media}

Berdasarkan bagan 02, total rerata yang diperoleh dari validasi terhadap ahli media adalah 3,68 dan bila dikonversikan pada tabel penilaian termasuk dalam kategori layak. Secara rinci, rerata dari ahli media 1 sebesar 3,75 yang jika dikonversikan ke tabel penilaian tergolong dalam kategori layak. Sedangkan, perolehan rerata dari ahli media 2 sebesar 3,62 yang jika dikonversikan ke tabel penilaian juga tergolong dalam kategori layak.

Berdasarkan rekomendasi dari ahli media, MUE direvisi terutama pada aspek kualitas tampilan khususnya penempatan gambar/foto pada layar. Foto diatur sedemikian rupa secara berurut dan sistematis untuk mendapatkan tampilan yang menarik. Penilaian terhadap konten materi dilakukan oleh tim validasi pustakawan. Berikut adalah grafik hasil validasi pustakawan. 


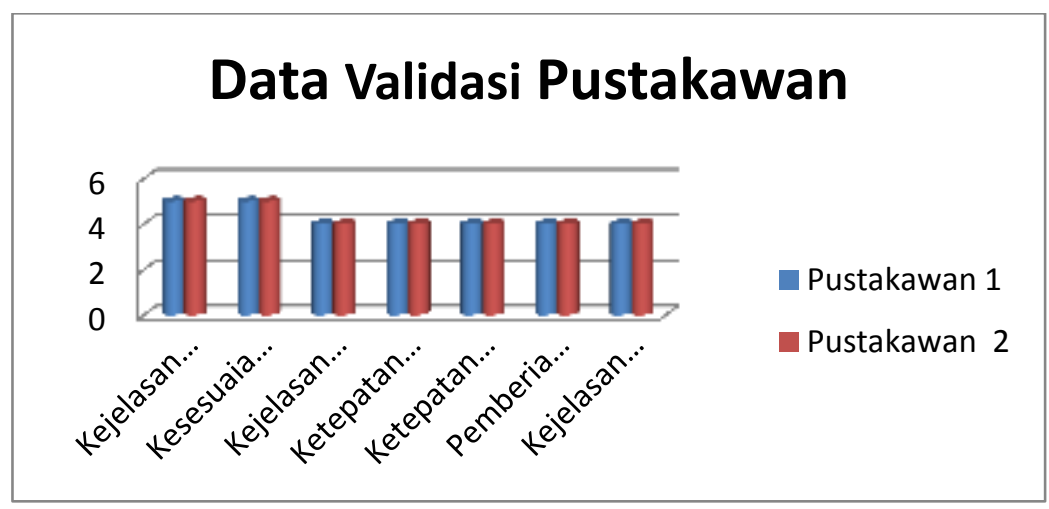

Grafik 2. Data Validasi Pustakawan

Berdasarkan hasil validasi pustakawan, total rerata yang diperoleh adalah sebesar 4,29 yang jika dikonversikan ke dalam tabel penilaian, maka tergolong sangat layak. Kelayakan MUE dapat terlihat dari kejelasan tujuan MUE, materi, ketepatan animasi, motivasi dan kebahasaan. Hal ini menegaskan kembali penilaian dari ahli media yang menyatakan bahwa MUE layak untuk diimplementasikan.

Terkait dengan perolehan rerata dari kedua ahli (ahli media dan pustakawan), maka media pendidikan pemustaka (MUE) layak untuk diimplementasikan sebagai alat bantu instruksional dalam memberikan bimbingan kepada pemustaka.

Terkait dengan hasil ujicoba MUE terhadap 50 responden, total rerata yang diperoleh adalah sebesar $88,1 \%$. Angka tersebut mengindikasikan bahwa MUE sangat efektif diimplementasikan pada perpustakaan Undiksha dalam kegiatan pendidikan pemustaka. Berikut adalah persentase untuk masing-masing konstruk dalam angket.

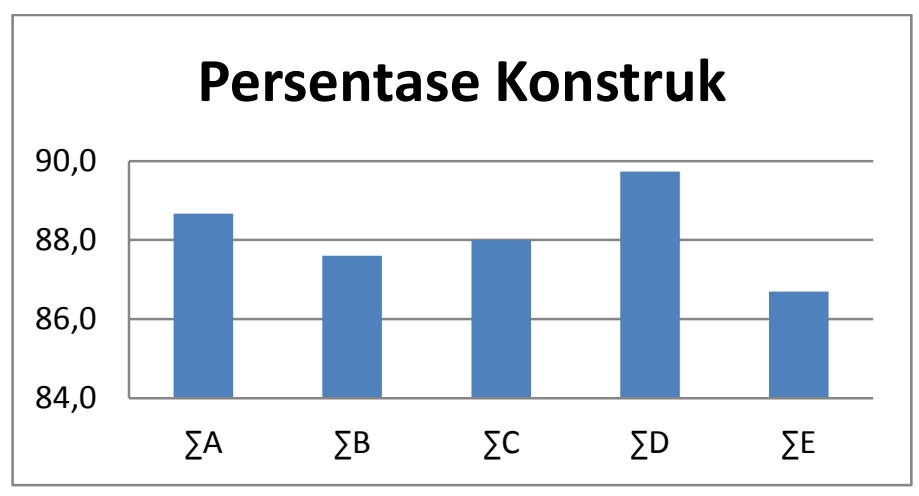

Grafik 3. Persentase konstruk angket MUE 
Ket.

$\sum \mathrm{A}=$ Materi MUE

$\sum \mathrm{B}=$ Relevansi MUE

$\sum \mathrm{C}=$ Kepuasan pemustaka

$\sum \mathrm{D}=$ Pengetahuan

$\sum \mathrm{E}=$ Sikap pemustaka terhadap MUE

Berdasarkan bagan 04, konstruk pengetahuan memperoleh skor tertinggi dengan persentase sebesar 89,7 \%. Hal ini menunjukkan bahwa MUE mampu meningkatkan pengetahuan pemustaka baru terhadap seluk beluk perpustakaan Undiksha. Selanjutnya, konstruk materi memperoleh skor 88,7 \% yang menunjukkan bahwa materi yang termuat dalam MUE sangat sesuai dengan kebutuhan informasi yang diinginkan oleh pemustaka baru mulai dari tata ruang, layanan dan fasilitas, tata tertib, sistem informasi perpustakaan, dan SDM yang mengelola perpustakaan. Persentase konstruk kepuasan adalah sebesar $88 \%$ yang menunjukkan bahwa MUE mampu memenuhi harapan responden akan keterlibatan teknologi dalam kegiatan pendidikan pemustaka. Sedangkan, persentase konstruk relevansi MUE adalah sebesar 87,6 \% yang mengindikasikan bahwa MUE sangat bermanfaat sebagai alat bantu instruksional dalam pendidikan pemustaka untuk mengenalkan dan sekaligus mendorong serta menghilangkan keraguan pemustaka baru untuk memanfaatkan sumber daya yang tersedia di perpustakaan Undiksha. Dan, perolehan persentase konstruk sikap pemustaka terhadap MUE adalah sebesar 86,7 \%. Hal ini menunjukkan bahwa pemustaka memiliki sikap sangat positif terhadap MUE. MUE mampu menumbuhkan sikap percaya diri pemustaka dalam memanfaatkan serta menjaga keutuhan koleksi setelah menonton MUE. Disamping itu, MUE dinyatakan mampu menumbuhkan kedekatan pemustaka dengan pustakawan sehingga pustakawan dianggap sebagai patner mahasiswa/pemustaka dalam meraih kesuksesan.

Sejalan dengan hasil angket, hasil wawancara terhadap responden mengungkap bahwa MUE merupakan strategi pendidikan pemustaka yang sangat relevan di era digital natives yang dicirikan dengan keterlibatan teknologi dalam 
pelayanan. Responden merasa termotivasi dan tidak merasa canggung lagi berkunjung ke perpustakaan. Pengetahuan yang diperoleh dari MUE secara signifikan mampu meningkatkan sikap pemustaka baru untuk memanfaatkan sumber daya yang tersedia di perpustakaan dan membentuk pemustaka sebagai pebelajar yang mandiri. Responden juga menyarankan agar MUE di desiminasikan melalui sosial media, sehingga informasi yang termuat dalam MUE tersebar lebih cepat tanpa batasan ruang dan waktu ke seluruh mahasiswa Undiksha.

\section{PENUTUP}

Multimedia user education (MUE) telah berhasil dikembangkan melalui model Luther. Enam tahap pengembangan telah dilalui dalam proses pengembangan MUE yaitu dari tahap concept, design, material collecting, assembly, testing, dan distribution.

Berdasarkan hasil validasi ahli media diperoleh rerata sebesar 3,68 yang mengindikasikan bahwa MUE termasuk dalam kategori layak. Sedangkan, berdasarkan hasil validasi ahli pustakawan diperoleh rerata sebesar 4,29 yang mengindikasikan bahwa MUE termasuk dalam kategori sangat layak. Terkait dengan perolehan rerata tersebut, maka dapat ditarik simpulan bahwa MUE layak untuk diimplementasikan sebagai alat bantu instruksional dalam kegiatan pendidikan pemustaka terutama bagi pemustaka baru.

Berdasarkan hasil ujicoba skala besar, diperoleh persentase rerata sebesar 88,1 $\%$. Perolehan tersebut mengindikasikan bahwa MUE sangat efektif digunakan sebagai media pendidikan pemakai. Kebermanfaatan MUE tercermin dari pernyataan responden yang menyatakan bahwa MUE mampu memberi pemahaman dan sekaligus memotivasi serta menghilangkan keraguan pemustaka baru untuk memanfaatkan sumber daya yang tersedia di perpustakaan Undiksha.

\section{DAFTAR PUSTAKA}

Barfield, L. 2004. Design for New Media: Interaction Design for Multimedia and the Web. England: Pearson Edu. Ltd. 
Basuki, S. 1993. Pengantar Ilmu Perpustakaan. Jakarta: PT Gramedia.

Bungin, B. 2008. Analisis Penelitian Kualitatif: Pemahaman Filosofis dan Metodologis ke Arah Penguasaan Model Aplikasi. Jakarta: Raja Grafindo Persada.

Chapman, N. \& Chapman, J. 2004. Digital Multimedia (2 ${ }^{\text {nd }}$ ed). London: John Wiley \& Sons, Ltd.

Constantinescu, A. I. 2007. Using Technology to assist in Vocabularly Acquisition and Reading Comprehension. The Internet ESL Journal, Vol XII, No. 2. http://iteslj.org/Articles/Constantinescu-Vocabularly.html.

Faisal, Sanapiah. 2008. Format-Format Penelitian Sosial. Jakarta: PT Rajagrafindo Persada

Hermawan, R. \& Zen, Z. 2010. Etika Kepustakawanan: suatu Pendekatan terhadap Kode Etik Pustakawan Indonesia. Jakarta: Sagung Seto.

Janiansyah. $2009 . \quad$ Pengertian Multimedia. https://janiansyah.wordpress.com/2009/05/15/pengertian-multimedia/

Junaeti. 2013. Pendidikan Pemustaka di Perpustakaan STAIN Pekalongan. www.Junaetiblogspot.com

Kamus Besar Bahasa Indonesia edisi ke 3. 2005. Jakarta: Balai Pustaka.

Mardina, R. 2011. Potensi Digital Natives dalam Representasi Literasi Informasi Multinedia Berbasis Web di Perguruan Tinggi. Jurnal Pustakawan Indonesia Vol.11 No.1.

Prensky, M. 2001. Digital Natives and Digital Immigrants.

On The Horrizon Vol. 9 No 5.

Setyowati, L. 2014. Teknologi Informasi dan Komunikasi: Peluang dan Tantangan bagi Perpustakaan dalam Merengkuh Pengguna. Jurnal Perpustakaan Universitas Airlangga. Vol. 4, No. 1.

Soedibyo, N. 1987. Pengelolaan Perpustakaan (Jilid 1). Bandung: Penerbit Alumni.

Sudatha, I G W. \& tegeh, I. M. 2009. Desain Multimedia Pembelajaran. Buku Ajar yang didokumentasikan di perpustakaan undiksha.

Sutarno. 2006. Manajemen Perpustakaan: suatu Pendekatan Praktik. Jakarta: Sagung Seto.

Sutopo, A. H. 2003. Multimedia Interaktif dengan Flash. Yogyakarta: Graha Ilmu.

Suyanto, B. \& Sutinah. 2007. Metode Penelitian Sosial: berbagai alternative pendekatan. Jakarta: Kencana Prenada Media Group.

Utami. P. 2012. Sikap terhadap Teknologi Informasi dalam Memberikan Layanan di Era Digital Natives. Makalah yang disampaikan pada Seminar Ilmiah Perpustakaan Universitas Pendidikan Ganesha.

UU RI No 43 tahun 2007. Jakarta: Depdiknas

Wati, U.A. 2010. Pengembangan Multimedia Pembelajaran untuk Mata Kuliah Pembelajaran Terpadu. Jurnal Ilmu Pendidikan. Thn. 1, No. 1.

Webster's New World Dictionary. 1994. New York: Prentice Hall. 